\title{
Characterization of Polyphenols from Various Cocoa (Theobroma cacao L.) Clones During Fermentation
}

\author{
Muhammad Isa Dwijatmoko ${ }^{{ }^{* *}}$, Budi Nurtama ${ }^{1)}$, Nancy Dewi Yuliana ${ }^{1)}$ and Misnawi ${ }^{2)}$ \\ ${ }^{1)}$ Departement of Food Science and Technology, Faculty of Agriculture Technology, Bogor Agricultural University (IPB), \\ Jl. Raya Dramaga Kampus IPB Darmaga Bogor 16680, West Java, Indonesia \\ ${ }^{2}$ Indonesian Coffee and Cocoa Research Institute, Jl. PB. Sudirman 90, Jember, Indonesia \\ ${ }^{*}$ Corresponding author email: juliana.luthfia@gmail.com \\ Received: 14 March 2018 / Accepted: 3 July 2018
}

\begin{abstract}
Cocoa bean is a rich source of polyphenols, which are the largest group secondary metabolite with natural antioxidant property. Polyphenols from cocoa beans was reported to possess health benefits. Fermentation, one step in cocoa processing is needed to improve the quality of cocoa in which the concentration of cocoa bean polyphenols might decrease significantly through oxidation and exudation. Cocoa polyphenols content among different cocoa clones might also vary. The aims of this study were to determine total polyphenols, total flavanoid, epicatechin, and catechin content in several cocoa clones, those were Sulawesi 1, Sulawesi 2, ICCRI 03, and KW 617. Until now, characterization of polyphenols from those clones has not been reported. The effect of five days fermentation to those parameters was also studied. The results of the study showed that fermentation and type of clones significantly affected total of polyphenols, total of flavanoids, epicatechin, and catechin content of the cocoa, there is also an interaction between fermentation and type of clones. Unfermented of Sulawesi 1 had the highest total polyphenols of $96.94 \pm 5.83 \mathrm{mg} / \mathrm{g}$, total flavanoids of $90.92 \pm 1.89 \mathrm{mg} /$ $\mathrm{g}$, epicatechin of $52.50 \pm 0.46 \mathrm{mg} / \mathrm{g}$, and catechin of $1.99 \pm 0.02 \mathrm{mg} / \mathrm{g}$ content compared to other clones. Among five days fermented cocoa beans, Sulawesi 2 showed the highest total polyphenols and total flavanoids content, while ICCRI $03 \mathrm{had}$ the highest epicatechin and catechin content than other clones. Thus, in can be concluded that although fermentation is required to improve the flavor quality of cocoa, it significantly reduced the content of bioactive compounds. This effect varied among different cocoa clones.
\end{abstract}

Keywords: cacao, catechin, clone, epicatechin, fermentation, polyphenols

\section{INTRODUCTION}

Cocoa (Theobroma cacao L.) plants are widely grown in Indonesia. ICCO (2017) reported that Indonesia's cocoa estimated production in 2017 reached 330.000 tons, so Indonesia is the biggest cocoa producer after Ivory Coast (1.900.000 tons) and Ghana (850.000 tons). The high production is not in line with the quality of Indonesia cocoa beans, especially related to fermentation and filth. In Indonesia, only 10\% cocoa bean is further processed with fermentation which impacts to the quality of exported Indonesian cocoa (Suharyanto, 2013).

Fermentation is the key process for cocoa beans to produce good flavor quality. Unfermented cocoa beans can not develop specific aroma cocoa when they are roasted, 
even still strong in astringent and bitter taste. These type of beans are not favoured by cocoa manufactures (Misnawi et al., 2002). Polyphenols are compunds which responsible for bitter and astringent flavour. Bitterness and astringent are usually due to lack of fermentation (End \& Dand, 2015).

Basically, fermentation in cocoa beans is aimed to remove mucilage from cocoa beans and to develop a number of flavor precursors in cocoa (Nigam \&Singh, 2014). Generally, fermentation process is conducted for five days (Towaha, 2014). Spontaneous fermentation of cocoa beans can be conducted in wooden box containers, in baskets, with or wihout addition of microbial starter cultures. Cocoa beans are processed into product such as cocoa powder, chocolate and other cocoa derivative products (Oracz et al., 2015). Cocoa has higher total polyphenols, flavonoids, and antioxidant activity than black tea, green tea, and red wine (Lee et al., 2003).

Cocoa is rich source of polyphenols, in particular flavanols, also known as flavan3 -ols or catechins, especially with its high content of monomeric (epicatechin and catechin) and oligomeric (procyanindins) flavanols (Rusconi \& Conti, 2010; Alanon et al., 2016). These polyphenols, especially flavonoid have beneficial effects for human health. Cocoa polyphenols have role as antioxidant that provide various effect against several pathological disorders, such as cardiovascular disease, inflammatory process, and cancer (Andujar et al., 2012; Oracz et al., 2013). Epicatechin is a major polyphenols in chocolate and chocolate extracts, powerful inhibitor of plasma lipid oxidation (Vinson et al., 2006).

Diversity in varieties, geographical location, climate condition, and post harvest processing may affect the chemical composition and organoleptic characteristic of cocoa beans, for example cocoa trees grown on West Africa is characterized as bitter in flavour and less aromatic, than the seeds form the plantations in Indonesia (Oracz et al., 2013). Niemenak et al. (2006) reported total polyphenols content in cocoa beans from Cameroon was diverse and ranged from 67.0 to $149.2 \mathrm{mg} / \mathrm{g}$, and cocoa beans from Indonesia was $82.3 \mathrm{mg} / \mathrm{g}$ (Towaha, 2014).

During the transformation of fresh cocoa beans to finished products, the polyphenols content can be affected by a variety of biological and processing conditions (Oracz et al., 2013). Thus, the study of polyphenols chracterization from various cocoa clones, fermented and unfermented, is necessary to be conducted.

\section{MATERIALS AND METHOD}

Cocoa beans of Sulawesi 1, Sulawesi 2, ICCRI 03, and KW 617 clones were obtained from Kaliwining Research Station of Indonesian Coffee and Cocoa Research Institute, Jember with elevation $45 \mathrm{~m}$ asl., rainfall $2.130 \mathrm{~mm} /$ year, and air temperature $19.6^{\circ} \mathrm{C}-32.5^{\circ} \mathrm{C}$. The research used completely randomized design with two factors as four clones and two treatment of fermentation and each combination treatment was repeated two times. Each measurement was also repeated two times.

Cocoa beans used in this study were taken from ripe cocoa pods were cleaned and the beans were taken out from the pods. Preparation of the cocoa bean samples was conducted at Kaliwining Research Station, Indonesian Coffee and Cocoa Research (ICCRI) Jember. Cocoa beans were divided into two groups: five days fermented and unfermented groups. Fermentation of cocoa beans was conducted using batch insert fermentation 
technique for small scale fermentation. Cocoa beans were wrapped with shading net, then put either in wooden box $(40 \mathrm{~cm} \times 40 \mathrm{~cm}$ $x 50 \mathrm{~cm}$ ) at $45-48^{\circ} \mathrm{C}$ (fermented group) or directly dried in the dry house (unfermented group). Then, cocoa beans were dried for five days and peeled manually to obtain the nibs. Cocoa nibs were roasted at temperature $116^{\circ} \mathrm{C}$ for 25 minutes, then the cocoa nibs were ground to form a cocoa liquor.

Cocoa liquor was defatted with Soxhlet method using petroleum ether for seven hours. The defatted residue (cocoa powder) was air dried and stored in refrigerant (Luna et al., 2002). Method of cocoa powder's total polyphenols and flavonoids extraction refers to Misnawi (2003). A total $250 \mathrm{mg}$ of defatted cocoa powders was sonicated using $40 \mathrm{~mL}$ of $80 \%$ aqueos acetone (Smart $\mathrm{Lab}$ ) in a Sonicor (Ultrasonic LC $30 \mathrm{H}$ ) for 30 minutes. During sonication, the mixture was kept cold by filling the sonicator vessel with ice water. Then, these crude extract was filtered using vacuum filtration through Whatman no. 1 filter paper to obtaine purified extract (residue). The residue was washed with the $80 \%$ aqueos acetone and total volume of the extract was made up $50 \mathrm{~mL}$. Method of cocoa powder extraction to obtain epicatechin and catechin followed a method of Shumow \& Bodor (2011). Defatted samples were extracted using a mixture of acetone : water : acetic acid $(70: 29.5: 0.5)$ followed by sonication at $40^{\circ} \mathrm{C}$ for 10 minutes and centrifugation for 10 minutes. This steps were repeated twice. Total volume of the extract was made up $25 \mathrm{~mL}$. Then, the extract was filtered with Whatman no. 14 filter paper and PTFE $0.45 \mu \mathrm{m}$ paper, respectively.

A total $1 \mathrm{~mL}$ of purified extract was diluted with $70 \mathrm{~mL}$ of distilled water. The extracted polyphenols was then reacted with $5 \mathrm{~mL}$ of $2 \mathrm{~N}$ Folin - Ciocalteau reagen for two minutes. Then $15 \mathrm{~mL}$ of saturated $\mathrm{Na}_{2} \mathrm{CO}_{3}$ solution was added to stabilize the color formed. The blue color was allowed to develop for two hours and it's absorbance was measured at $765 \mathrm{~nm}$. Acid gallate $(\mathrm{mg} / \mathrm{g})$ standar was used for calculation (Misnawi, 2003)

A total $125 \mu \mathrm{L}$ of extract was added to $75 \mu \mathrm{L} \mathrm{NaNO}_{2} 5 \%$ solution. The mixture was allowed to stand six minutes, then $150 \mu \mathrm{L}$ $\mathrm{AlCl}_{3} 10 \%$ was added and incubated for five minutes followed by the addition of $750 \mu \mathrm{L}$ $\mathrm{NaOH} 1 \mathrm{M}$. The final volume was adjusted to $2500 \mu \mathrm{L}$ with distilled water. After 15 minutes of incubation and it's absorbance was measured at $510 \mathrm{~nm}$. Catechin $(\mathrm{mg} / \mathrm{g})$ standar was used for calculation (Rebaya et al., 2014).

Epicatechin and catechin content were determined using the modified method of Shumow \& Bodor (2011). $5 \mu \mathrm{L}$ was injected to the LC-20AD (Shimadzu) detector PDA $278 \mathrm{~nm}$. Seperation of epicatechin and catechin was accomplished in $\mathrm{C} 18$ reversed phase analytical column using water $(0.2 \%$ acetic acid) : acetonitril $(0.2 \%$ acetic acid) $(85: 15)$ as a mobile phase at flow rate $0.5 \mathrm{~mL} / \mathrm{min}$ with column temperature $40^{\circ} \mathrm{C}$.

Data analysis were performed by the software SAS for Windows (Version 9.1.3) and SIMCA 13.0.2. If the result of variance was significant difference between tratments, then continued with Duncan Multiple Range Test with $\alpha=5 \%$.

\section{RESULTS AND DISCUSSION}

Various components from raw cocoa beans contribute in specific cocoa flavors formation by changes during processing, such as alkaloids (methylxanthines), polyphenols, protein, and carbohydrates (Aprotosoaie et al., 2016). Fermentation of cocoa beans 
is one of steps in cocoa post harvest processing. It is generally carried out through a spontaneous fermentation either in heaps, box, baskets, tray, or on platform (Papalexandratou et al., 2011). Fresh cocoa beans contain pigment in white to deep purple colour, depending on the amount of anthocyanin (Camu et al., 2008). During fermentation anthocyanin is converted into anthocyanidin, results in bleaching of the purple color of the bean (Vuyst \& Weckx, 2016)

The microorganism is responsible in spontaneous cocoa fermentation and their physiological roles during process. Papalexandratou et al. (2011) reported that in cocoa bean fermentation process, there is a colonization by yeast, lactic acid bacteria, and acetic acid bacteria, which produces ethanol, lactic acid and acetic acid. These compounds then diffuse into the beans, and cause the death of the seed embryo. Next, a complex physical processes and biochemical reactions are initiated in the beans to form the required flavor and color precursors. Other microbial metabolites such as ester and pyrazines, may enter the cotyledons of bean and act as flavour precursors or directly as flavour compound (Camu et al., 2008).

This study showed that fermented and unfermented cocoa beans and their clones exhibited significantly different result of total polyphenols, total flavonoids, catechin, and epicatechin content. During fermentation process, cocoa beans polyphenols are oxidized to form condensed high molecular weight compounds, such as tannin (Nazaruddin et al., 2006; Camu et al., 2008). The oxidation is catalyzed by polyphenoloxidase enzyme. The polyphenols are oxidized into o-quinones which then forming a complex with amino acids, proteins, and undergo polymerization with flavonoids to form tannins that produce brown colour (Afoakwa et al., 2012). The enzymes cause a substrate destruction, then giving brown colour (Wahyudi et al., 2015).
The results of this study showed that fermented and unfermented cocoa beans showed significantly different polyphenols content regardless different clones (Table 1). Decrement of total polyphenols, total flavanoids, epicatechin, and catechin content during fermentation time were affected by the fermentation time. Hurst et al. (2011) reported that fermentation decreased the level of epicatechin. Albertini et al. (2015) also reported that fermentation process for two days decreased polyphenols content significantly, but changes in polyphenols content after six days fermentation were less significant.

Table 2 showed that quantity of these compounds also depended on the varietal characteristics of cocoa. Total polyphenols and total flavonoids of Sulawesi 2 were the highest among all clones, while KW 617 was the lowest. Total polyphenols of Sulawesi 2 was significantly different compared to Sulawesi 1 and KW 617, but not significantly different from ICCRI 03, which total polyphenols of Sulawesi $2>$ ICCRI $03>$ Sulawesi $1>\mathrm{KW}$ 617. Total flavonoid of Sulawesi 2 was significantly different from other clones, but Sulawesi 1 was not significantly difference with ICCRI 03 , which is total flavonoids Sulawesi $2>$ ICCRI $03>$ Sulawesi $1>$ KW 617. Then, the clone with the highest epicatechin and catechin content was ICCRI 03, while the lowest was KW 617. Epicatechin and catechin content of ICCRI 03 was significantly difference with other clones, which is epicatechin and catechin content ICCRI $03>$ Sulawesi $1>$ Sulawesi $2>$ KW 617. In other study, Niemenak et al. (2006) reported that different cocoa clones, such as SNK 10, SNK 413, and ICS 84 had different phenolic compound content, that content could be an interaction of several factors such as genetics, physiological, agronomic, and environment factor. 
Table 1. Total polyphenols, total flavanoids, epicathechin, and catechin content in fermented and unfermented cocoa powder

\begin{tabular}{|c|c|c|c|c|}
\hline Treatment & $\begin{array}{c}\text { Total polyphenols } \\
(\mathrm{mg} / \mathrm{g})\end{array}$ & $\begin{array}{l}\text { s Total flavonoids } \\
(\mathrm{mg} / \mathrm{g})\end{array}$ & $\begin{array}{c}\text { Epicatechin } \\
(\mathrm{mg} / \mathrm{g})\end{array}$ & $\begin{array}{c}\text { Catechin } \\
(\mathrm{mg} / \mathrm{g})\end{array}$ \\
\hline Unfermented & $75.635^{\mathrm{a}}$ & $70.570^{a}$ & $37.653^{\mathrm{a}}$ & $1.501^{\mathrm{a}}$ \\
\hline Fermented & $55.939^{b}$ & $41.012^{\mathrm{b}}$ & $18.280^{b}$ & $0.871^{\mathrm{b}}$ \\
\hline
\end{tabular}

Note: Numbers within the same column with same letter are not significantly different at $5 \%$ level according to Duncan test.

Table 2. Total polyphenols, total flavanoids, epicatechin, and catechin from different clones of cocoa powder

\begin{tabular}{lcccc}
\hline Clones & $\begin{array}{c}\text { Total polyphenols Total flavonoids } \\
(\mathrm{mg} / \mathrm{g})\end{array}$ & $\begin{array}{c}\text { Epicatechin } \\
(\mathrm{mg} / \mathrm{g})\end{array}$ & $\begin{array}{c}\text { Catechin } \\
(\mathrm{mg} / \mathrm{g})\end{array}$ \\
\hline Sulawesi 1 & $69.311^{\mathrm{b}}$ & $59.319^{\mathrm{b}}$ & $31.485^{\mathrm{b}}$ & $1.332^{\mathrm{b}}$ \\
Sulawesi 2 & $73.764^{\mathrm{a}}$ & $64.225^{\mathrm{a}}$ & $27.276^{\mathrm{c}}$ & $1.252^{\mathrm{c}}$ \\
ICCRI 03 & $72.595^{\mathrm{a}}$ & $59.467^{\mathrm{b}}$ & $39.021^{\mathrm{a}}$ & $1.462^{\mathrm{a}}$ \\
KW 617 & $47.480^{\mathrm{c}}$ & $40.153^{\mathrm{c}}$ & $14.084^{\mathrm{d}}$ & $0.696^{\mathrm{d}}$ \\
\hline
\end{tabular}

Note: Numbers within the same column with same letter are not significantly different at $5 \%$ level according to Duncan test.

To explain the effect of fermentation on polyphenols content of different cocoa clones, principal component analysis (PCA) was applied to all samples. The PCA bi-plot is presented in Figure 1. In the bi-plot, fermented cocoa and unfermented cocoa groups are clearly separated from each other, which means that fermentation significantly changed cocoa polyphenols content. Fermented cocoa is grouped on the left part of the plot while the unfermented one was on the right. KW 617 clone was the exception. Unfermented KW 617 is clustered close to fermented KW 617 which means that fermentation of KW 617 cocoa beans had less effect on its polyphenols content. It can be seen in Table 3 that for example total polyphenols of unfermented Sulawesi 1 was reduced more than $50 \%$ after fermentation $(96.94 \pm 5.83 \mathrm{mg} / \mathrm{g}$ to $41.68 \pm 2.81$ $\mathrm{mg} / \mathrm{g}$ ), whereas total polyphenols of unfermented KW 617 only reduced slightly after fermentation $(48.80 \pm 1.94 \mathrm{mg} / \mathrm{g}$ to $46.16 \pm$ $0.87 \mathrm{mg} / \mathrm{g}$ ).

Unfermented Sulawesi 1 had a higher total polyphenols, total flavonoids, catechin and epicatechin content than other fermented or unfermented clones, followed by ICCRI 03, Sulawesi 2, and KW 617. Sulawesi 1 was reported to be more resistance aginst VSD disease than other clones (Hadi et al., 2014). Prawoto et al. (2013) reported that polyphenols content of resistant clones was higher, it might be because a secondary metabolite was inducible resistance mechanism. Resistant clones contained 22\% more components than the susceptible.

Polyphenols content of all clones decreased after fermentation process at different decrement level (Table 3). This might be explained by the difference of polyphenols oxidase (PPO) activity level. PPO is catalyzing reactions for several phenols to produce o-quinones from o-hydraxylation of monophenols (monophenolase activity) and the oxidation of odiphenols into o-quinones (diphenolase activity) with oxygen as the primary oxidant (Yoruk \& Marshall, 2003). Among others, Sulawesi 1 showed the most prominent decrease in all parameters measured in this study (total polyphenols, total flavonoid, epicatechin and catechin content)

PPO enzyme activity is mostly determined by external factors, such as $\mathrm{pH}$. Polyphenol oxidase activity is sensitive against $\mathrm{pH}$ changes (Misnawi, 2008). The $\mathrm{pH}$ optimum of PPO varies widely with plant source but is generally in the range of 4.0-8.0, such as cherry has $\mathrm{pH}$ optimum with estimated 
maximum at about 4.5 and the ratio of monophenolase to diphenolase activity varies depending on plant sources (Yoruk \& Marshall, 2003). In cocoa Macedo et al. (2016) reported that $\mathrm{pH}$ optimal for PPO in pulp extract was 6.5-6.6 and for seed exract the optimal $\mathrm{pH}$ was 5.8-6. Clone and fermentation are not the only factors influenced cocoa polyphenols content, other factors such as drying, roasting, and dutch processing, can affect a flavanol content (Hurst et al., 2011).

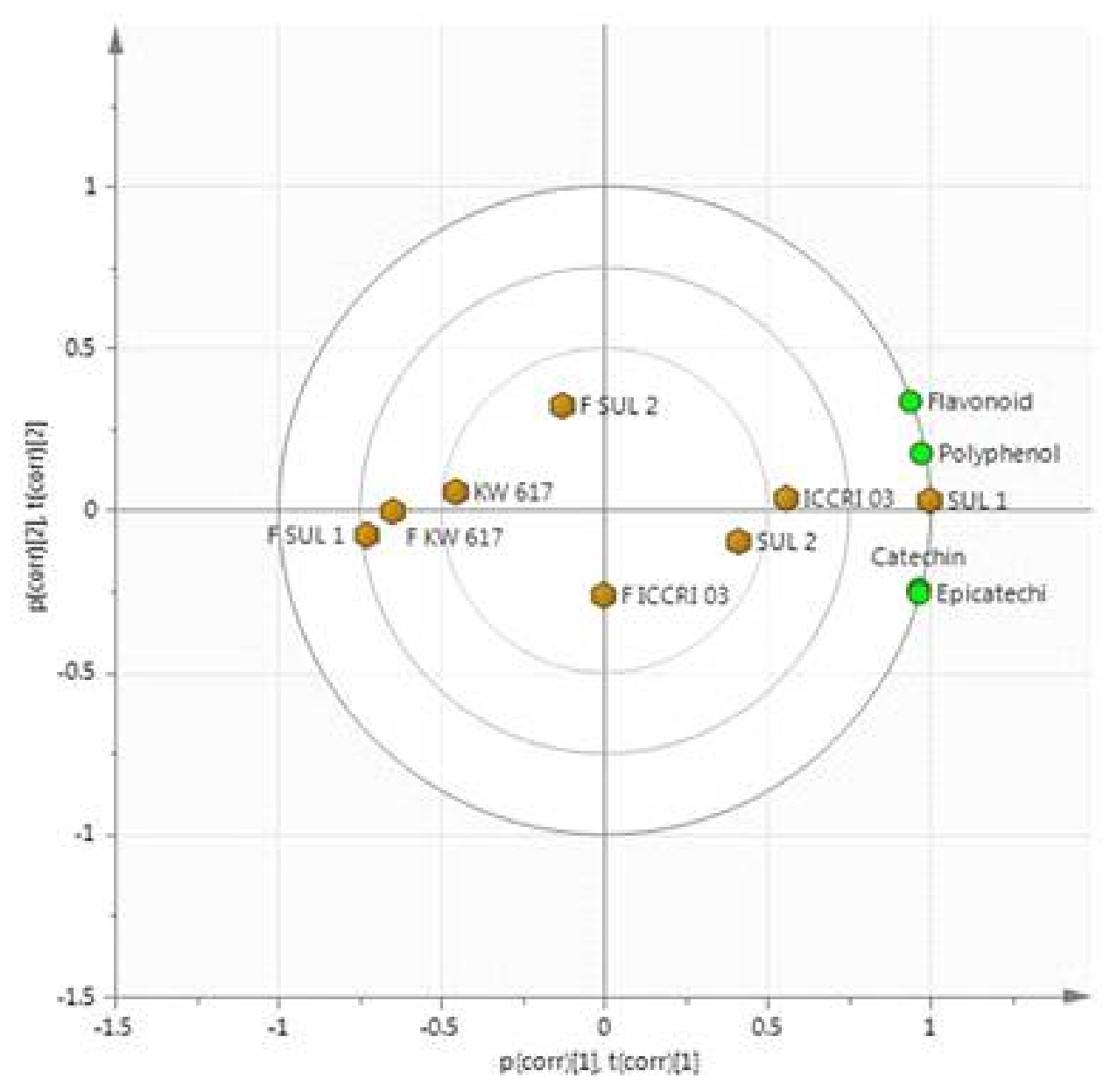

PC 1: $92.2 \%$ PC2: $6.7 \%$

$$
\text { OComponent OSample }
$$

Figure 1. Principal component analysis on fermented and unfermented cocoa powder on total of polyphenols, total of flavanoids, epicathechin, and catechin indeks (F Sul 1= fermented Sulawesi 1, F Sul 2 = fermented Sulawesi 2, F ICCRI 03 = fermented ICRRI 03, F KW 617 = fermented KW 617; Sul $1=$ unfermented Sulawesi 1 , Sul 2 = unfermented Sulawesi 2, ICCRI 03 = unfermented ICCRI 03, KW 617 = unfermented KW 617) 
Table 3. Total polyphenols, total flavanoids, epicatechin, and catechin from different clones of cocoa powder

\begin{tabular}{|c|c|c|c|c|}
\hline Clones & $\begin{array}{c}\text { Total polyphenols } \\
(\mathrm{mg} / \mathrm{g})\end{array}$ & $\begin{array}{c}\text { Total flavonoids } \\
(\mathrm{mg} / \mathrm{g})\end{array}$ & $\begin{array}{c}\text { Epicatechin } \\
(\mathrm{mg} / \mathrm{g})\end{array}$ & $\begin{array}{c}\text { Catechin } \\
(\mathrm{mg} / \mathrm{g})\end{array}$ \\
\hline \multicolumn{5}{|l|}{ Unfermented } \\
\hline Sulawesi 1 & $96.937 \pm 5.83$ & $90.915 \pm 1.89$ & $52.502 \pm 0.46$ & $1.991 \pm 0.02$ \\
\hline Sulawesi 2 & $75.388 \pm 4.95$ & $66.182 \pm 2.64$ & $38.945 \pm 0.07$ & $1.676 \pm 0.04$ \\
\hline ICCRI 03 & $81.416 \pm 4.09$ & $78.382 \pm 1.88$ & $43.120 \pm 0.31$ & $1.571 \pm 0.03$ \\
\hline KW 617 & $48.798 \pm 1.94$ & $46.799 \pm 3.22$ & $16.047 \pm 0.04$ & $0.759 \pm 0.04$ \\
\hline \multicolumn{5}{|l|}{ Fermented } \\
\hline Sulawesi 1 & $41.684 \pm 2.81$ & $27.723 \pm 2.08$ & $10.467 \pm 0.18$ & $0.675 \pm 0.01$ \\
\hline Sulawesi 2 & $72.140 \pm 3.67$ & $62.298 \pm 1.89$ & $15.607 \pm 0.15$ & $0.829 \pm 0.03$ \\
\hline ICCRI 03 & $63.772 \pm 1.08$ & $40.551 \pm 2.26$ & $34.923 \pm 0.36$ & $1.347 \pm 0.02$ \\
\hline KW 617 & $46.160 \pm 0.87$ & $33.507 \pm 1.89$ & $12.121 \pm 0.07$ & $0.631 \pm 0.00$ \\
\hline
\end{tabular}

\section{CONCLUSIONS}

Total of polyphenols, total of flavonoids, epicathechin, and catechin content were affected by fermentation process and type of clones. Unfermented cocoa beans have higher total polyphenols, total flavonoids, epicathechin, and catechin content than the fermented ones. Cocoa clone of Sulawesi 1 had the highest content of the above mentioned compounds than other clones, but during fermentation the content was dramatically decreased. Among the fermented samples, the fermented beans of Sulawesi 2 clone had the highest total of polyphenols and total of flavonoids, while the fermented beans of ICCRI 03 clone had the highest epicathechin and catechin content. Changes in polyphenols content due to fermentation as described in this study might affect health beneficial effect of the cocoa, such as its antioxidant activity, and it can produce good flavour quality.

\section{ACKNOWLEDGEMENTS}

The authors are grateful to Indonesian Coffee and Cocoa Research Institute (Jember, Indonesia) for helping in sample preparation and analysis. We also thanks to Indonesia Endowment Fund for Education (LPDP) for supporting this research.

\section{REFERENCES}

Afoakwa, E.O.; J. Quao; F.S. Takrama; A.S. Budu \& F.K. Saalia (2012). Changes in total polyphenols, o-diphenols and anthocyanin concentrations during fermentation of pulp pre-conditioned cocoa (Theobroma cacao) beans. International Food Research Journal, 19, 1071-1077.

Alanon, M.E.; S.M. Castle; P.J. Siswanto; C. Gomez \& J.P.E. Spencer (2016). Assessment of flavanol stereoisomers and caffeine and theobromine content in commercial chocolate. Food Chemistry, 208, 177-184.

Albertini, B.; A. Schoubben; D. Guarnaccia; F. Pinelli; M.D. Vecchia; M. Ricci; G.C.D Renzo $\&$ P. Blasi (2015). Effect of fermentation and drying on cocoa polyphenols. Journal of Agricultural and Food Chemistry, 63, 9948-9953.

Aprotosoaie, A.C.; S.V. Luca \& A. Miron (2016). Flavor chemistry of cocoa and cocoa products-an overview. Comprehensive Reviews in Food Science and Food Safety, 15, 73-91.

Andujar, I.; M.C. Recio; R.M. Giner \& J.L. Rios (2012). Cocoa polyphenol and their potential benefits for human health. Oxidative Medicine and Cellular Longevity, 2012, 1-23.

Camu, N.; T.D. Winter; S.K. Addo; J.S Takrama; H. Bernaert \& L.D. Vuyst (2008). Fermen- 
tation of cocoa beans: Influence of microbial activtities and polyphenol concentrations on the flavour of chocolate. Journal of The Science of Food and Agriculture, 88, 2288-2297.

End, M.J. \& R. Dand (2015). Cocoa Beans/: Chocolate \& Cocoa Industry Quality Requirements. CAOBISCO/ECA/FCC, Brussel, Belgia.

Hadi; H.B. Hudoro; M. Novariyanthy; I.I. Tanjung; Mutowil; M.I. Soedjana \& I. Mulyono (2014). Good Agricultural Practices/ GAP on Cocoa. Direktorat Jenderal Perkebunan. Kementerian Pertanian, Jakarta.

Hurst, W.J.; S.H. Krake; S.C. Bergmeier; M.J. Payne; K.B. Miller \& D.A. Stuart (2011). Impact of fermentation, drying, roasting, and dutch processing on epicatechin and catechin content of cacao beans and cocoa ingredients. Journal Chemistry Central, 5, 1-8.

ICCO (2017). Quarterly Bulletin of Cocoa Statistics. International Cocoa Organization. Abidjan, Côte d'Ivoire.

Luna, F.; D. Crouzillat; L. Cirou \& P. Bucheli (2002). Chemical composition and flavour of ecuadorian cocoa liquor. Journal of Agriculture and Food Chemistry, 50, 3527-3532.

Macedo, A.S.L.; F.D.S. Rocha; M.D.S. Riberiro; S.E. Soares \& E.D.S. Bispo (2016). Characterization of polyphenol oxidase in two cocoa (Theobroma cacao L.) cultivars produced in the south of Bahia, Brazil. Food Science and Technology Campinas, 36, 56-63.

Misnawi; J. Selamat; J. Bakar \& N. Saari (2002). Oxidation of polyphenols in unfermented and partly fermented cocoa beans by polyphenol oxidase and tyrosine. Journal of The Science of Food and Agriculture, 82, 559-566.

Misnawi (2003). Influences of Cocoa Polyphenols and Enzyme Reactivation on The Flavor Development of Unfermented and Under-Fermented Cocoa Beans.
PhD thesis. Universiti Putra Malaysia, Kuala Lumpur, Malaysia.

Misnawi (2008). Physico-chemical changes during cocoa fermentation key enzymes involved. Review Penelitian Kopi dan Kakao, 24, 47-64.

Nazaruddin, R.; L.K Seng; O. Hassan \& M. Said (2006). Effect of pulp preconditioning on the content of polyphenols in cocoa beans (theobroma cacao) during fermentation. Industrial Crops and Products an International Journal, 24, 87-94.

Niemenak, N.; C. Rohsius; S. Elwers; D.O. Ndoumou \& R. Lieberei (2006). Comparative study of different cocoa (Theobroma cacao L.) clones in terms of their phenolics and anthocyanins contents. Journal of Food Composition and Analysis, 19, 612-619.

Nigam, P.S. \& A. Singh (2014). Cocoa and coffee fermentations. p. 466-473. In: Encyclopedia of Food Microbiology, C.A. Batt \& M.L. Tortorello (Eds). Vol. 1.

Oracz, M.J.; D. Zyzelewich \& E. Nebesny (2013). The content of polyphenolic compund in cocoa beans (theobroma cacao l.), depending on variety, growing region and processing operations: a review. Critical Review in Food Science and Nutrition, 55, 1176-1192.

Papalexandratou, Z.; N. Camu; G. Falony \& L.D. Vuyst (2011). Comparison of the bacterial species diversity of spontaneous cocoa bean fermentation carried out at selected farms in invory coast and brazil. Food Microbiology, 28, 964-973.

Prawoto, A.A.; T.I. Santoso; Marifah; L. Hartanto \& Sutikno (2013). Terpene profile, leaf anatomy, and enzyme activity of resistant and susceptible cocoa clones to vascular streak diback disease. Pelita Perkebunan, 29, 197-209.

Rusconi, M. \& A. Conti (2010). Theobroma cacao L., the food of the gods: A scientific approach beyond myth and claims. Pharmacoligical Research, 61, 5-13. 
Rebaya, A.; S.I. Belghith; B. Baghdikian; V.M. Leddet; F. Mabrouki; E. Olivier; J.K. Cherif \& M.T. Ayadi (2015). Total phenolic, total flavonoid, tannin content, and antioxidant capacity of Halimium halimifolium (Cistaceae). Journal of Applied Pharmaceutical Science, 5, 052-057.

Shumow, L. \& A. Bodor (2011). An industry consensus study on an hplc fluorescence method for the determination of $( \pm)$-catechin and $( \pm)$-epicatechin in cocoa and chocolate products. Journal Chemistry Central, 5, 1-7.

Suharyanto, E. (2013). Potensi pengolahan kakao di Indonesia. Seminar Pangan Nasional. Solo, 19 Oktober 2013.

Towaha, J. (2014). Polyphenol content in cocoa beans and its contribution for health. SIRINOV, 2, 1-16.

Wahyudi, T; Pujiyanto \& Misnawi (2015). Kakao: Sejarah, Botani, Proses Produksi, Pengolahan, dan Perdagangan. Gadjah Mada University Press, Yogyakarta.
Vinson, J.A.; J. Proch; P. Bose; S. Muchler; P. Tafeera; D. Shuta; N. Samman \& G.A. Agbor (2006). Chocolate is a powerful ex vivo and in vivo antioxidant, an antiatheroscelerotic agent in an animal model, and a significant contributor to antioxidants in the European and American diets. Journal of Agricultural and Food Chemistry, 54, 8071-8076.

Vuyst, L.D. \& S. Weckx (2016). The functional role of lactic acid bacteria in cocoa bean fermentation. p. 248-273. In: Biotechnology of Lactic Acid Bacteria Novel Applications. F. Mozzi, R. Raya \& G.M. Viguolo (Eds.). Chichester, West Sussex.

Yoruk, R. \& M.R. Marshall (2003). Physicochemical properties and function of plant polyphenol oxidase: A review. Journal of Food Biochemistry, 27, 361-422.

$* * 0 * *$ 